with a wider field of activities than a development branch of the Geological Survey which would be restricted to the study of minerals, including peat. This department should co-ordinate every stage of development from survey to production and carry out the experimental work which existing organizations are not equipped to do, as.well as serve as an institution for giving additional training to the technical men who will develop and eventually run the new industries. Apart from its references to seaweed and peat, the memorandum gives very little indication of what materials call for the creation of a new department to investigate Scottish resources. Neglect of those resources will be readily admitted, but it is net clear from this memorandum why their investigation and development could not be undertaken as part of the general national research effortwhy, for example, separate Scottish research into housing is required.

\section{Astronomy and the Struve Family}

Os the occasion of the award of the 1944 Gold Medal of the Royal Astronomical Society to Prof. Otto Struve, the president of the Society, Prof. E. A. Milne, reviewed the astronomical work of the Struves, which has been recognized by four awards of the Gold Medal to the family in 118 years-once in each generation (Mon. Not. Roy. Astr. Soc., 104, 112; 1944). Wilhelm Struve, founder of the Pulkovo O'servatory, received the Gold Medal in 1826 for his work in discovering and measuring double stars. $\mathrm{His}$ son, an earlier $\mathbf{O}$ to Struve, was awarded it in 1850 for a paper on "The Determination of the Constant of Precession with respect to the Proper Motion of the Solar System". The third medallist was Hermann Struve, uncle of the present holder, who gained the award in 1903 for his monumental work on the satellites of Saturn. This year's award goes to Prof. Otto Struve, director of the Yerkes and McDonald Observatories, and great-grandson of Wilhelm, for his observation and interpretation of the spectra of stars and nebulæ. Prof. Milne reviewed this work in some detail, and pointed out that the present medallist has followed the family tradition in founding a new observatory, and has exceeded it in directing not merely one but simultaneously two great observatories. In his power of execution of new projects, in the width and generality of the problems he has selected and attacked, and in the brilliance of his solution of these problems, said Prof. Milne, Otto Struve has worthily carried the family fame in a new branch of astronomy to a new continent, and made good.

\section{Telepathy in Psychoanalysis}

Dr. H. J. Ehrenwald, formerly of Prague, has directed attention to the possibility of telepathy in the psychoanalytic situation (Brit. J. Med. Psych., 20, Pt. 1 ; 1944). It is well known to psychical researchers that since Freud mentioned this factor in his new series of introductory lectures, his pupils have obediently followed him and are themselves now at pains to discuss the question in relation to their own patients. In this paper, Dr. Ehrenwald extends these observations not only regarding telepathy from patient to analyst but also from analyst to patient. He mentions some of Freud's own cases, including the famous case of his patient, Mr. P., which Freud thought to be very suggestive, but which few psychical researchers would regard as worthy of serious consideration. What is, however, of more interest in Dr. Ehrenwald's paper is his obvious anxiety to warn his colleagues of the possibility of telepathy occurring during sittings with their patients, and the implications which can be derived from it. From the point of view of the psychical researcher this attitude is somewhat divert. ing, since for so many years psychoanalysts have declined to learn what parapsychologists could have taught them and now, having become almost convinced through Freud's influence that telepathy exists, present examples of it which exhibit so many sources of error that it is clear that they still have little appreciation of the problems on which they write. If Dr. Ehrenwald's paper disturbs still further their complacency, it will have performed a useful service.

\section{Chinese Journal of Agricultural Science}

Thж British Council made a very happy choice in selecting Dr. J. Needham for its seientific mission in China. $\mathrm{He}$ has been indefatigable in promoting scientific work in that part of the country which remains in Chinese hands and in his efforts to keep British scientific workers informed about Chinese work. Since the outbreak of the War, most of the scientific journals in China have been discontinued, and in consequence those keen spirits that still go on with their scientific studies have their difficulties increased by the lack of any means of publication. A new journal has now been started by the Ministry of Agriculture and Forestry at Chungking, and the first issue is to hand. Among other papers are two on inheritance in wheat. One on dwarfness deals with the complex ratios obtained in counts of the $F_{2}$ progenies of the varietal crosses made in 1939 ; seven factors are assigned, of which three are complementary, three are duplicates of these and one is an inhibitor; the combinations necessary for dwarfness are discussed. The other paper is a mathematical discussion of Japanese data on the pentaploid hybrids of wheat. Trials are recorded of the Winogradksy Azotobacter plaque method for estimating potash and phosphate deficiencies in soils: this was found to be rapid and easily worked and seems likely to prove very valuable if its indications are borne out in practice. Other papers deal with the extraction of nicotine from tobacco leaves; the orange maggot (Tetradacus sp.); and a possible vermicidal plant, Tripterygium wilfordii. The papers are in Chinese, but with summaries in English. We wish the new journal all success.

\section{University of London}

Mr. T. H. Marshall has been appointed as from October 1 to the University chair of social institutions tenable at the London School of Economics. Since the beginning of the War he has worked in the Foreign Office Research Department, as head of the German Section since the autumn of 1940, and as deputy director since the spring of 1943.

Mrs. Barbara Wootton has been appointed as from October 1 to the University readership in social studies tenable at Bedford College. Since 1927 she has been director of studies for tutorial classes in the University and has acted as visiting lecturer in the Department of Social Studies at Bedford College for some years.

The title of professor of chemistry in the University has been conferred on Dr. E. E. Turner, in respect of the post held by him at Bedford College. 